\title{
Analyzing the Connotation of Mao Zedong's Nationalism
}

\author{
Yonghong Zhang \\ Correspondence: Yonghong Zhang, School of Marxism, Research Center for Marxist Theory, Southwest \\ University, Chongqing 400715, China. Tel: 86-138-8336-0756. E-mail: zyyhhh867@ sohu.com
}

\author{
Received: August 8, 2013 Accepted: August 21, 2013 Available online: October 21, 2013 \\ doi:10.11114/ijsss.v2i1.242 URL: http://dx.doi.org/10.11114/ijsss.v2i1.242
}

This paper is supported by the Fundamental Research Funds for the Central Universities "A Comparative Study of Democratic Socialism and Socialism with Chinese Characteristics" (SWU1009034).

\begin{abstract}
Combined with China's reality, Mao Zedong's nationalism characteristic of the age came into being during the revolutionary practice. The pith of it is anti-imperialism and anti-feudalism; The final aim of it is to realize socialism and communism; Internationalism is its reasonable kernel; To further the equality, unity and prosperity of all the ethnicities in the country is one of its significant prospects; And to stick to the principle of giving priority to self-dependence and striving for foreign aid as auxiliary is its concernful content. For the Chinese people who have entered into a new era, Mao's nationalism is still a precious fortune.
\end{abstract}

Keywords: Mao Zedong, nationalism, connotation

\section{Introduction}

Generally speaking, nationalism is the national emotion and national values formed in the struggle of a nation for its own interests, dignity and future. In other words, nationalism is a kind of ideology based on the national emotion; it is a kind of love and loyalty of the members of the national community for their own nation, including the inheritance and maintenance by the national members of the common national borders, customs, laws, memory, language, art and religious expression, social system and life style, etc. It is customary to think that communism is opposite to nationalism, and "workers of all countries, unite!" is the pursuit of communism. However, the reality tells us that whether "international route" or "globalization" which was or is used by some countries is mixed with their nationalist route. That communism must be united with interests of the nation-state is also a profound summary of the revolutionary experience in modern China. The reason why Mao Zedong and a number of early Chinese Marxists chose Marxism as an ideological and theoretical weapon is that they believed the Marxist doctrine was one of the most effective means to realize the nationalist appeal. Mao Zedong was not only a great communist, but also a nationalist. His nationalism was generated and constantly adjusted with the development of the revolution and construction practice and has a rich connotation and strong vitality. Though Mao Zedong's nationalism is valuable, writings involved in it are quite limited both at home and abroad. The main articles in this scope are" some discussions on the characteristics of Mao Zedong's nationalism" by Caihua and "a comparison of Mao Zedong's nationalism with that of Chiang kai-shek's during the Anti-Japanese War" by Zhang Fengqing. Other related studies can be found in works concerning Mao Zedong's patriotism and national self-confidence, such as "the formation and development of Mao Zedong's patriotism" by Zheng Zhenbang," Mao Zedong's patriotism and the great national revival" by Jing Degen and "on Mao Zedong's national self-confidence" by Zhaohui. Today, a deeper research and discussion on Mao Zedong's nationalism can not only help us deepen the study of Mao Zedong Thought, but is good for us to look at various nationalist sentiments popular in the world today with a more sober mind. This paper will focus on the connotation of Mao Zedong's nationalism by analyzing relevant study achievements, Mao Zedong's life experience and revolutionary practice.

\section{Resolutely Uncompromising Anti-imperialist and Anti-feudal Spirit is the Core of Mao Zedong's Nationalism}

In 1840, the British launched the opium war and opened the door of ancient China. Since then, Chinese people started the long journey of salvaging the country. Like many of his contemporaries, young Mao Zedong was 
influenced by all kinds of new thoughts and new theories. Before becoming a firm Marxist, he had been a sucker for "democracy of the 19th century", the Utopian socialism and the old liberalism, but there is no doubt that he was against warlords and imperialism.

The imperialist aggression made Mao Zedong realize soberly that no compromise worked, so the Chinese people had to "hone themselves to save themselves and protect their children". He also strongly attacked the feudal warlords, called on people to emancipate their minds and struck down power politics. Mao Zedong wrote, "Don't be afraid of the heaven, don't be afraid of ghosts, don't be afraid of the dead, don't be afraid of bureaucrats, don't be afraid of warlords, and don't be afraid of capitalists." This, obviously, is a reflection of his fearless revolutionary spirit.

Mao Zedong's great theoretical achievement "the New-Democracy Theory", in a sense, reflects his nationalism, and the formation process of Mao Zedong's New-Democracy Theory illustrates a spiritual journey of his nationalism to sublimation. He pointed out that "the so-called New-Democracy Revolution is the people's anti-imperialist and anti-feudal revolution under the leadership of the proletariat".

Mao Zedong's nationalism full of anti-imperialist and anti-feudal spirit and patriotic feelings became the basis for cooperation between the Communist Party of China and other classes and political parties. As Harvard University professor Schwartz, an expert in Chinese modern history, argues that the fact that Marxism, liberalism and conservatism came together in modern China shows that they shared some common ideas, among which, the ferment of nationalist sentiment was an important one.

\section{To Achieve Socialism and Communism is the Ultimate Goal of Mao Zedong's Nationalism}

In the process of leading Chinese revolution, Mao Zedong combined Lenin's theory of national colony with characteristics of the Chinese history and put forward the famous theory of two-step actions for the Chinese revolution, which solved the problem of the relations between the Chinese national-democratic revolution and the socialist revolution.

Mao Zedong argued, "a change, however, occurred in China's bourgeois-democratic revolution after the outbreak of the first imperialist world war in 1914 and the founding of a socialist state on one-sixth of the globe as a result of the Russian October Revolution of 1917.Before these events, the Chinese bourgeois-democratic revolution came within the old category of the bourgeois-democratic world revolution, of which it was a part. Since these events, the Chinese bourgeois-democratic revolution has changed, it has come within the new category of bourgeois-democratic revolutions and, as far as the alignment of revolutionary forces is concerned, forms part of the proletarian-socialist world revolution".

Nationalism pursues the principle that the political and national units should be congruent and to establish nation-states is an ideal for nationalists. Mao Zedong was no exception; but he didn't limit his vision to the construction of a nation-state but put his eyes on the distant future of China. Mao Zedong emphasized in his well-known article "the Chinese revolution and the Communist Party of China" that the ultimate prospect of the Chinese revolution was not capitalism but socialism and communism. Thus, the aim of Mao Zedong's nationalism was not only to fight for national independence and freedom, but also to build a new socialist China. At this point, Mao Zedong tied modern nationalism to the proletariat revolution and made it step into a new stage.

\section{Internationalism is the reasonable kernel of Mao Zedong's nationalism}

Internationalism is the reasonable kernel of Mao Zedong's nationalism. As early as the end of 1920, Mao Zedong argued in his letter to Cai Hesen that "we need more international color and it's necessary to articulate this solemnly now", and that we Chinese people "would certainly work in China but feelings need to be universal and we can't just love this place."[6]During the Anti-Japanese War, Mao Zedong summarized theoretically that "the Chinese communists must combine patriotism with internationalism. China's victory.......would also mean a help to the people in foreign countries. Therefore, nationalism is the implementation of internationalism in the national liberation war".

In the article "in Memory of Norman Bethune", Mao Zedong interpreted his internationalism quite clearly. He said, "Leninism teaches that the world revolution can only succeed if the proletariat of the capitalist countries supports the struggle for liberation of the colonial and semi-colonial peoples and if the proletariat of the colonies and semi-colonies supports that of the proletariat of the capitalist countries........We must unite with the proletariat of all the capitalist countries, with the proletariat of Japan, Britain, the United States, Germany, Italy and all other capitalist countries, for this is the only way to overthrow imperialism, to liberate our nation and people and to liberate the other nations and peoples of the world. This is our internationalism, the internationalism with which we oppose both narrow nationalism and narrow patriotism". 
It must be pointed out that Mao Zedong put much emphasis on internationalism but never sacrificed national legitimate interests. According to the traditional opinion, "Marxism and nationalism cannot be reconciled". But Mao Zedong got a perfect combination of both. The Communist Party of China at its early stage copied the Soviet experience and followed the guidelines given by the Soviet Union, which, as a result, caused a series of major setbacks. It was Mao Zedong who found a route in line with China's reality, as being in China's best national interests, and eventually freed the Communist Party of China of the control by the Soviet Union and came forward to a path leading to success. This route carried on into the founding of new China and has survived to today's reform and opening up to the outside world.

\section{To Achieve Equality, Unity and Prosperity of All Ethnic Groups is an Important Aspect of Mao Zedong's Nationalism}

China is a multi-ethnic country. Ethnic discrimination and oppression policies carried out by feudal rulers left a mark on ethnic inequality, ethnic hatred among ethnic groups. In allusion to this national condition, Mao Zedong pointed out in the Sixth Plenary Session of the Sixth CPC Central Committee that the ethnic minorities should be allowed to have equal rights as the Han ethnicity, and while anti-Japanese was the general principle, they had a right to manage their own affairs. Besides, all ethnic groups should unite to establish a unified country. Mao Zedong adhered to the principle of ethnic equality and unity, and all the words which went against this principle were opposed to by him. For Chiang Kai-shek's argument that minorities didn't exist in China, Mao Zedong pointed out, "the Kuomintang, which is against the people, denies that China is a multi-ethnic country, and calls other ethnicities 'patriarchal clans'. They fully inherit the reactionary policy followed by the Qing government and the Northern warlords' government, in which exploitation and oppression are pervasive". Mao Zedong agreed with Sun Yat-sen's national policy that "all ethnicities in China are equal and should have a free and unified Republic of China organized after the victory of revolution". Mao Zedong made it clear that the Communist Party of China not only fully agreed to Mr. Sun's national policy, but that "the Communist Party must actively help the people from various minorities strive for the realization of the policy". It follows that the nationalism Mao Zedong advocated is that all ethnic groups at home are equal. In October 1947, Mao pointed out more explicitly that the CPC "admits the right to equal autonomy for all the minorities of China". After the victory of the New-Democratic Revolution, the regional autonomy in minority areas has been practiced in China according to the principle of ethnic autonomy. Practice has proved that this policy adapts to the complex national conditions in china and plays a huge role in consolidating the national unity and promoting common development and prosperity of all ethnic groups. But, due to the gap, suspicion and mistrust between various ethnic groups in the long history, there is still contradiction and struggle between them, which behaves mainly as Han chauvinism and local nationalism. In his important speech "Ten Major Relationships" issued in 1956, Mao Zedong summed up the experience in dealing with the relationship between Han ethnicity and minorities. He said," we focus on Han chauvinism. Local nationalism must be opposed too, but generally that is not where our emphasis lies". He stressed in the following year, "the key to this question lies in overcoming Han chauvinism. Where there is local nationalism among ethnic minorities, local nationalism should also be overcome. Both Han chauvinism and local nationalism go against the unity of the people of all ethnic groups......."

In a word, to insist on ethnic equality, strengthen national unity, develop national economy and culture and take the path of common prosperity of various ethnicities is an important aspect of Mao Zedong's nationalism. Today, in some places in China, local nationalism and ethnic separatism as opposed to Han chauvinism are gaining ground, in the face of which, we need to revisit the thought of Mao Zedong's nationalism and take it as our ideological weapon to fight resolutely against whatever scheme which goes against the unity of all ethnicities.

\section{To Develop Ourselves by Adhering to the Way in Which We Rely Primarily on Our Own and Take Foreign Aid as Auxiliary Is an Important Content of Mao Zedong's Nationalism}

To achieve national independence and liberation and realize national prosperity and people's common prosperity has been two major historical tasks of China since the 1840s, and was also the basic purpose of modern nationalism. To this end, fighting unsupported wouldn't do and the policy of opening to the outside world and striving for foreign aid should be carried out. As early as the period of the Anti-Japanese War, Mao Zedong, from the perspective of the united front, put forward the idea of two "footholds". He pointed out that to drive the Japanese invaders out of China required three conditions: Unity of all the Chinese people; Unity of the anti-war, anti-invasion, anti-fascist countries in the world; and the consciousness of the Japanese people. Among them, the unity of all Chinese people was the key to China's victory over Japan, so "China should have self-reliance as the basic foothold", but "China is not isolated and shouldn't be isolated, and the fact that China is closely linked to the world is also our foothold". The relatively relaxed political environment after the basic formations of the anti-Japanese national united front made Mao Zedong try to seek economic cooperation with the United States. 
In July 1944, Mao Zedong theoretically expounded in a talk with the U.S. Army observation group that this cooperation was not only necessary, but also possible, because "China's greatest need after the war is the development of economy, but China lacks the necessary capitalist basis of completing this task independently". The United States and China could complement each other economically, and "use the principle of free trade between countries to replace Japan's principle of colonizing China". He even said that if Roosevelt agreed, he himself (or Zhou Enlai) would like to travel to Washington to meet him. After the founding of new China in 1949. China could only be one-sided politically due to the severe international environment, but at the same time, Mao Zedong advocated that China actively develop friendly diplomatic relations with all the countries of the world on the basis of the principle of equality, taking the initiative to strive to do business with as many countries as possible, including Britain, France, the Netherlands, Belgium, Canada, USA, Japan and other capitalist countries.

In Mao Zedong's view, to rely primarily on our own and take foreign aid as auxiliary is equally important for both the Chinese revolution and construction. Mao Zedong advocated and practiced this principle in the entirety of his life. He once said, "We hope for foreign aid but cannot be dependent on it; we rely on our own efforts and the creativity of the army and the people."Although this principle was sometimes biased in practice in the past, it is impeccable in theory and provides the theoretical guidance and practical model for future generations. We may say that without this principle, the great power of Mao Zedong's nationalism could have been discounted.

\section{Conclusion}

Nationalism is a double-edged sword. As a kind of ideology, it advocates that each nation should respect and protect its national language, history and culture, and establish a unified political country. As a kind of thought, a national spirit and a political mobilization means, it plays a role in stimulating and uniting the members of a nation. In history, the establishment of the European nation-states, the independence movements in Latin America and the national liberation movements in Africa and Asia all showed the unique appeal of nationalism. But, meanwhile, national split, genocide, ethnic hatred in some countries also had a relationship to the overemphasis of nationalism. As far as the contemporary nationalisms are concerned, we can say that they are varied and their development trends are elusive. In this case, a careful analysis of the reasons of different nationalisms and the establishment of mechanism of peaceful settlement of ethnic issues are important means to solve contemporary ethnic problems. Today, a research of Mao Zedong's nationalism could probably provide us with a reference and plenty of food for thought.

How could we describe Mao Zedong's nationalism? All in all, in decades of revolutionary practice, Mao Zedong formed his own nationalism with scientificity and time spirit on the basis of China's national conditions and a full sublation of modern nationalism, thus developing modern nationalism into a new stage. Like modern nationalism, Mao Zedong's nationalism also includes both resistance and construction, which, in his own words, "strives for the complete liberation of the Chinese nation externally and promotes domestic equality between ethnicities internally". His nationalism is neither Han chauvinism nor local nationalism but the nationalism at the level of the Chinese nation, which is consistent with patriotism in essence and has showed its power in practice. It's because this nationalism goes with the trend of historical development and can win the hearts of the people that the Communist Party of China could be able to obtain the victory of the New-Democratic Revolution and won one victory after another in the revolutionary cause and construction undertaking afterwards.

In the new era, Mao Zedong's nationalism isn't out of fashion; instead, it is being appreciated by more and more people in recent years. In the minds of the Chinese people, Mao Zedong is memorized and respected not only as a great leader of the Chinese people, but, he also becomes a big political cultural symbol and the attribute of the Chinese national consciousness and nationalism; Whenever China is faced with internal turmoil and external threat, the spirit of nationalism borne by his name could give people infinite passion and endless power. Today, against the background of trying our best to build a well-off society in an all-round way and realize great renaissance of the Chinese nation, we need to rule out all kinds of interference, cohere the people of all ethnicities of the country to form a powerful force. This new historical scene assigns significance to Mao Zedong's nationalism, and, in the coming days, it will certainly glow with new vitality.

\section{References}

Cao, Yueming. (1992, February5). Three trends of thought and nationalist movements in the Chinese modern history. Tianjin academy of social sciences.

Chen, Xueming. (2006, January15). Research review of the contemporary Chinese nationalism. Journal of Guangdong institute of socialism. 
Collection of letters of Xinmin society (set3).

Jing, Degen. (2006, February5). Mao Zedong's patriotism and the great national revival. Technology and education.

Li, Zhiguo. (1987, February15). Introduction to the formation and development of Mao Zedong' patriotism. Journal of Changchun teachers' college.

Mao, Zedong. (1938, November6). Report on the sixth plenary session of the communist party of China. Ning, Sao (1995). Nation and state. Beijing: Peking University Press.

Party History Research Center of the CPC Central Committee. (1983). Report of the party history, 20-21.

Yu, Yingshi. (1994). Aggressive and defensive positions in the intellectual history of modern China. Qianmu and the Chinese culture. Shanghai: Shanghai Far-East Publishing House.

Selected works of Mao Zedong (vol.5). (1977). Beijing: People's Publishing House.

Selected military works of Mao Zedong. (1981). Beijing: Warriors ' Publishing House.

Selected works of Mao Zedong (vol.2). (1991). Beijing: People's Publishing House.

Selected works of Mao Zedong (vol.3). (1991). Beijing: People's Publishing House.

Selected works of Mao Zedong (vol.4). (1991). Beijing: People's Publishing House.

Snow, Edgar. (1979). Red star over China, Beijing: The Joint Publishing Company LTD.

Wang, Zhanyang. (1993). Mao Zedong's image depicted by both Chinese and foreign journalists. Shenyang: Shenyang Press.

\section{(c) EY}

This work is licensed under a Creative Commons Attribution 3.0 License. 